\title{
Association between breast and thyroid cancers
}

This article was published in the following Dove Press journal:

Advances in Genomics and Genetics

20 February 2014

Number of times this article has been viewed

\section{Steven Lehrer \\ Sheryl Green \\ John A Martignetti \\ Kenneth E Rosenzweig}

Departments of Radiation Oncology and Genetics and Genomic Sciences, Icahn School of Medicine at Mount

Sinai, New York, NY, USA
Correspondence: Steven Lehrer Mount Sinai Medical Center Box 1236 , New York, NY 10029, USA

$\mathrm{Tel}+$ I 2127657132

Fax + I 2122459708

Email steven.lehrer@mssm.edu
Background: The risk of thyroid cancer is known to be slightly increased in women after treatment for breast cancer. In the current study, we analyzed the incidence of thyroid cancer and breast cancer in 50 US states and in the District of Columbia to ascertain how often these two diseases are associated.

Methods: Data on the incidence of thyroid cancer were obtained from the Centers for Disease Control and Prevention and the National Cancer Institute and data on the incidence of breast cancer were from the American Cancer Society. Data on the average number of children per family with children and mean household income were sourced from the US Bureau of the Census and prevalence of obesity by state is determined from a paper published in 2010 on state-specific obesity prevalence among US adults by the Centers for Disease Control and Prevention.

Results: There was a significant association between breast and thyroid cancer $(P=0.002)$. Since the incidence of breast cancer increases with increasing income and obesity, while decreasing with parity, multiple linear regression was performed. Breast cancer incidence was significantly related to thyroid cancer incidence $(\beta=0.271, P=0.039)$, inversely related to average number of children per family with children $(\beta=-0.271, P=0.039)$, unrelated to adult obesity $(\beta=0.134$, $P=0.369)$, and significantly related to family income $(\beta=0.642, P<0.001)$.

Conclusion: This study identifies an association between breast and thyroid cancer. The association suggests that unexplored breast-thyroid cancer susceptibility loci exist and warrant further study.

Keywords: breast cancer, thyroid cancer, genetics, association

\section{Introduction}

Harvey and Brinton reported that the risk of thyroid cancer is slightly increased in women after treatment for breast cancer. ${ }^{1}$ This increased risk of thyroid cancer is not entirely surprising, given that the thyroid is vulnerable to the carcinogenic action of ionizing radiation, especially in children. ${ }^{2}$ In one rare genetic condition, Cowden's disease, an autosomal dominant cancer predisposition syndrome, there is an elevated risk for a variety of tumors, most notably of the breast and thyroid. However, the breastthyroid cancer link has not been firmly established. ${ }^{3}$ In the current study, we analyzed the incidence of thyroid cancer and breast cancer in 50 US states and in the District of Columbia to ascertain how commonly these two diseases are associated.

\section{Materials and methods}

Data on the incidence of thyroid cancer were obtained from the Centers for Disease Control and Prevention and the National Cancer Institute, ${ }^{4}$ and data on the incidence 
of breast cancer were from the American Cancer Society. ${ }^{5}$ Data on the average number of children per family with children and mean household income were obtained from the US Bureau of the Census (http://www.census.gov). The prevalence of obesity by state was taken from a paper published in 2010 on state-specific obesity prevalence among US adults by the Centers for Disease Control and Prevention. ${ }^{6}$ State thyroid cancer and breast cancer data were analyzed as age-adjusted incidences in each of the 50 states and in the District of Columbia.

\section{Results}

There was a significant association between breast and thyroid cancer ( $P=0.002$, Figure 1$)$. Given that the incidence of breast cancer increases with increasing income and obesity, but decreases with increasing parity, ${ }^{7}$ multiple linear regression was performed. The incidence of breast cancer was significantly related to the incidence of thyroid cancer $(\beta=0.271$, $P=0.039$ ), inversely related to average number of children per family with children $(\beta=-0.271, P=0.039)$, unrelated to adult obesity $(\beta=0.134, P=0.369)$, and significantly related to family income $(\beta=0.642, P<0.001)$. We are unable to provide data regarding variability of the thyroid-breast cancer association by state, or any significant difference in the incidence of thyroid cancer prior to treatment for breast cancer patients.

\section{Discussion}

Our study identified an association between the development of breast cancer and thyroid cancer. The underlying cause

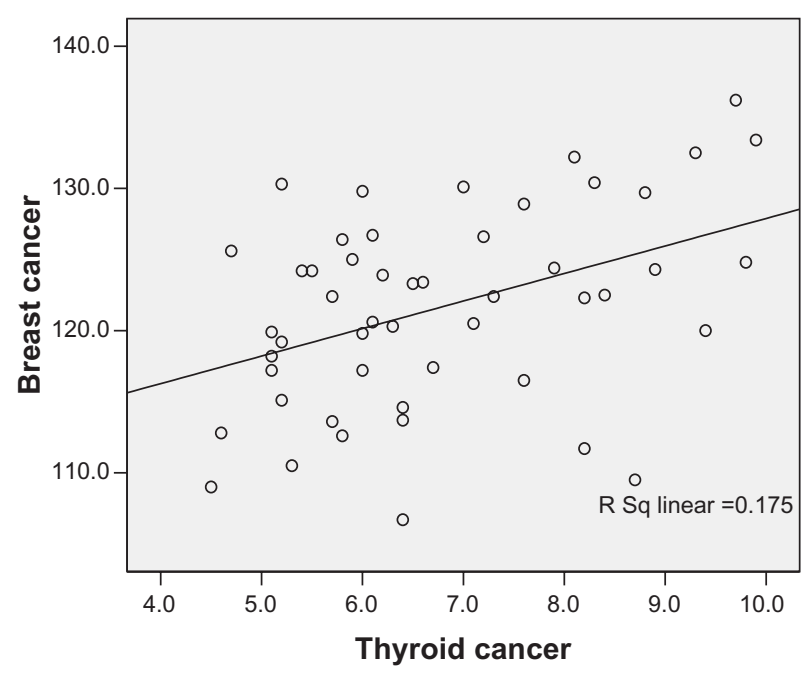

Figure I Age-adjusted breast cancer incidence versus age-adjusted thyroid cancer incidence per 100,000 in 50 US states and the District of Columbia. The association is significant $(P=0.002)$. for this association remains unknown. Cowden's disease, or multiple hamartoma syndrome, is a rare autosomal dominant familial cancer syndrome with a high risk of breast cancer and thyroid cancer. ${ }^{8}$ The highest age-associated risk of a female developing breast cancer is $85 \%$ and thyroid cancer risk is $35 \% .{ }^{9}$ Linkage analysis has demonstrated that a single locus within chromosome 10q23 is likely to be responsible. Mutations in the tumor suppressor gene PTEN at 10q23 predispose to Cowden's disease. ${ }^{10}$ However, Cowden's disease is quite rare, estimated to occur in one in 200,000 people. Therefore, it could be responsible for only a small proportion of the breast and thyroid cancers analyzed here.

The adult thyroid is much less susceptible to the carcinogenic effects of medical radiation than is the thyroid of a child, so that irradiation of the thyroid during breast cancer treatment would not be responsible for most of the thyroid cancers included in our analysis. ${ }^{2}$ Indeed, in the National Surgical Adjuvant Breast and Bowel Project, involving 818 women, only two cases of thyroid cancer occurred after breast irradiation. ${ }^{11}$

Breast cancer patients have an increased risk of thyroid function abnormalities. ${ }^{12}$ There are more thyroid autoantibodies in euthyroid patients with breast cancer compared with healthy controls, suggesting a possible relationship between breast cancer and autoimmune thyroid disease. ${ }^{13}$

Breast cancer susceptibility is likely due to a small number of highly penetrant mutations (such as in BRCA1 and BRCA2) and a much larger number of low-penetrance variants. However, germline mutations in BRCA1 and BRCA2 and a few other rare variants account for only $15 \%-20 \%$ of breast cancer that clusters in families and less than $5 \%$ of breast cancer overall. ${ }^{14}$ A genome-wide linkage search for breast cancer susceptibility genes has found candidate regions on chromosome 4 and chromosome $2 \mathrm{p} .{ }^{15}$ PALB2, which encodes a BRCA2-interacting protein and is a cause of Fanconi anemia, is also a breast cancer susceptibility gene. ${ }^{16}$ Also, there may still be other unrecognized susceptibility genes.

A search of the genome-wide association study literature for each of these individual cancers, ie, breast and thyroid, highlights at least three overlapping candidate breast-thyroid cancer susceptibility loci. The first locus is on chromosome $8 \mathrm{q} 24$. While the association with breast cancer has been validated across a number of studies, the most recent analysis in thyroid cancer, specifically analyzing rs6983267G, suggests that this association is present under a recessive model. ${ }^{17}$ The second locus is on chromosome 2q35. Recently, a single nucleotide polymorphism (SNP, rs966423) conferring a 
risk of thyroid cancer was identified ${ }^{18}$ and then validated using a second SNP (rs6759952) within the same linkage disequilibrium region in a follow-up study. ${ }^{19}$ Both SNPs are present within the DIRC3 gene. While the function of DIRC3 is unknown, it may affect thyroid hormone levels. ${ }^{18}$ Intriguingly, the breast cancer SNP rs13387042, identified in four independent studies, ${ }^{20-23}$ lies less than $250 \mathrm{~kb}$ downstream from DIRC3. A third familial breast-ovarian cancer locus may lie on chromosome 17q12-q23. ${ }^{24}$ Given our findings, the relationship between these SNPs, DIRC3, breast cancer, and thyroid cancer warrants further study.

A weakness in our analysis is possible confounding by the ecological fallacy (or ecological inference fallacy), a logical fallacy in the interpretation of statistical data where inferences about the nature of individuals are derived from inference for the group to which those individuals belong. ${ }^{25}$ In this case, inferences about individuals are being drawn from the characteristics of US states where they reside, rather than from the individuals themselves. Another intrinsic difficulty with correlational studies is that two variables may be associated, even if there is no causal link between them, if each is associated with some other variable.

Nevertheless, the frequency of the breast-thyroid cancer association described above suggests that additional breast cancer susceptibility genetic loci may remain to be identified and warrant further study.

\section{Disclosure}

The authors report no conflicts of interest in this work.

\section{References}

1. Harvey EB, Brinton LA. Second cancer following cancer of the breast in Connecticut, 1935-82. Natl Cancer Inst Monogr. 1985;68:99-112.

2. Ron E, Lubin JH, Shore RE, et al. Thyroid cancer after exposure to external radiation: a pooled analysis of seven studies. 1995. Radiat Res. 2012;178(2):AV43-AV60.

3. McTiernan A, Weiss NS, Daling JR. Incidence of thyroid cancer in women in relation to known or suspected risk factors for breast cancer. Cancer Res. 1987;47(1):292-295.

4. US Cancer Statistics Working Group. United States Cancer Statistics: 1999-2009 Incidence and Mortality Web-based Report. Department of Health and Human Services, Centers for Disease Control and Prevention and National Cancer Institute; 2013. Available from: http://www.cdc. gov/uscs. Accessed January 17, 2014.

5. American Cancer Society. Cancer Facts and Figures. 1-68. 2012. Atlanta, American Cancer Society.

6. Centers for Disease Control and Prevention (CDC). Vital signs: statespecific obesity prevalence among adults - United States, 2009. MMWR Morb Mortal Wkly Rep. 2010;59(30):951-955.
7. Madigan MP, Ziegler RG, Benichou J, Byrne C, Hoover RN. Proportion of breast cancer cases in the United States explained by well-established risk factors. J Natl Cancer Inst. 1995;87(22):1681-1685.

8. Nelen MR, Padberg GW, Peeters EA, et al. Localization of the gene for Cowden disease to chromosome 10q22-23. Nat Genet. 1996;13(1): 114-116.

9. Tan MH, Mester JL, Ngeow J, Rybicki LA, Orloff MS, Eng C. Lifetime cancer risks in individuals with germline PTEN mutations. Clin Cancer Res. 2012;18(2):400-407.

10. Liaw D, Marsh DJ, Li J, et al. Germline mutations of the PTEN gene in Cowden disease, an inherited breast and thyroid cancer syndrome. Nat Genet. 1997;16(1):64-67.

11. Fisher B, Dignam J, Wolmark N, et al. Lumpectomy and radiation therapy for the treatment of intraductal breast cancer: findings from National Surgical Adjuvant Breast and Bowel Project B-17. J Clin Oncol. 1998;16(2):441-452.

12. Giani C, Fierabracci P, Bonacci R, et al. Relationship between breast cancer and thyroid disease: relevance of autoimmune thyroid disorders in breast malignancy. J Clin Endocrinol Metab. 1996;81(3):990-994.

13. Rasmusson B, Feldt-Rasmussen U, Hegedus L, Perrild H, Bech K, Hoier-Madsen M. Thyroid function in patients with breast cancer. Eur J Cancer Clin Oncol. 1987;23(5):553-556.

14. Nathanson KL, Wooster R, Weber BL. Breast cancer genetics: what we know and what we need. Nat Med. 2001;7(5):552-556.

15. Smith P, McGuffog L, Easton DF, et al. A genome wide linkage search for breast cancer susceptibility genes. Genes Chromosomes Cancer. 2006;45(7):646-655.

16. Rahman N, Seal S, Thompson D, et al. PALB2, which encodes a BRCA2-interacting protein, is a breast cancer susceptibility gene. Nat Genet. 2007;39(2):165-167.

17. Jones AM, Howarth KM, Martin L, et al. Thyroid cancer susceptibility polymorphisms: confirmation of loci on chromosomes $9 q 22$ and 14q13, validation of a recessive $8 \mathrm{q} 24$ locus and failure to replicate a locus on 5q24. J Med Genet. 2012;49(3):158-163.

18. Gudmundsson J, Sulem P, Gudbjartsson DF, et al. Discovery of common variants associated with low TSH levels and thyroid cancer risk. Nat Genet. 2012;44(3):319-322.

19. Kohler A, Chen B, Gemignani F, et al. Genome-wide association study on differentiated thyroid cancer. J Clin Endocrinol Metab. 2013;98(10): E1674-E1681.

20. Fletcher O, Johnson N, Orr N, et al. Novel breast cancer susceptibility locus at 9q31.2: results of a genome-wide association study. $J$ Natl Cancer Inst. 2011;103(5):425-435.

21. Li J, Humphreys K, Heikkinen T, et al. A combined analysis of genomewide association studies in breast cancer. Breast Cancer Res Treat. 2011;126(3):717-727.

22. Stacey SN, Manolescu A, Sulem P, et al. Common variants on chromosomes 2q35 and 16q12 confer susceptibility to estrogen receptorpositive breast cancer. Nat Genet. 2007;39(7):865-869.

23. Turnbull C, Ahmed S, Morrison J, et al. Genome-wide association study identifies five new breast cancer susceptibility loci. Nat Genet. 2010;42(6):504-507.

24. Narod SA, Feunteun J, Lynch HT, et al. Familial breast-ovarian cancer locus on chromosome 17q12-q23. Lancet. 1991;338(8759):82-83.

25. Schwartz $\mathrm{S}$. The fallacy of the ecological fallacy: the potential misuse of a concept and the consequences. Am J Public Health. 1994;84(5): 819-824. 


\section{Publish your work in this journal}

Advances in Genomics and Genetics is an international, peer reviewed, open access journal that focuses on new developments in characterizing the human and animal genome and specific gene expressions in health and disease. Particular emphasis will be given to those studies that elucidate genes, biomarkers and targets in the development of new or improved therapeutic

interventions. The journal is characterized by the rapid reporting of reviews, original research, methodologies, technologies and analytics in this subject area. The manuscript management system is completely online and includes a very quick and fair peer-review system. Visit http://www.dovepress.com/ testimonials.php to read real quotes from published authors.

Submit your manuscript here: http://www.dovepress.com/advances-in-genomics-and-gene-expression-journal 